\title{
Effect Of Injection Timing On The Performance And Emissions Of Dual Fuel Engine Operated With Compressed Biogas And Calophyllum Inophyllum Methyl Ester
}

\author{
P.A. Harari \\ Assistant Professor, \\ Department of Mechanical Engineering, \\ Sant Gajanan Maharaj College of Engineering, Mahagaon, India \\ hararipraveen@gmail.com
}

\begin{abstract}
Emissions from engine exhaust are a serious problem for environment point of view. The search for an alternative fuel, which promises a harmonious correlation with sustainable development, energy conservation, management, efficiency and environmental preservation, has become highly pronounced in the present context. Dual fuel mode of operation employing Compressed Biogas (CBG) and biodiesel like Calophyllum Inophyllum Methyl Ester (CIME) is an attractive option as our country has a large agriculture base that can be a feed stock to this fuel technology and can ease the burden on the economy by curtailing the fuel imports. This paper presents the results of investigations carried out in studying the behaviour of CIME and subsequent testing of this oil in a four stroke, single cylinder, water cooled, direct injection CI engine in dual fuel mode with CBG induction. This paper studies the effects of Injection Timing (IT) and on performance and emissions of CBG dual fuelled with CIME in a dual-fuel engine. From the experimental evidence it is found that maximum brake thermal efficiency, maximum peak pressure and lower emissions were found at $27^{\circ} \mathrm{bTDC}$ injection timing.
\end{abstract}

Keywords-Calophyllum Inophyllum, Compressed biogas, Emission, Injection timing, Performance.

\section{INTRODUCTION}

Compression ignition (CI) engines are widely used as power source for automobile due to their high thermal efficiency, excellent fuel economy and low regulated emissions of unburned hydrocarbon $(\mathrm{HC})$, carbon monoxide $(\mathrm{CO})$ and carbon dioxide $\left(\mathrm{CO}_{2}\right)$ compared to those of spark ignition (SI) engines. From an environmental point of aspects, however, diesel engines generally exhaust a larger amount of particulate matter (PM) and nitrogen oxide (NOx) pollutant emissions than those of gasoline engines [1]. In recent years, the fossil-fuels have suffered from a sudden rise in prices because of the limitations of deposit, supply and considerable increases in demand for petroleum fuels resulting from the industrialization. Furthermore, the regulations for PM and NOx emissions from diesel engines have strengthened, and reductions in $\mathrm{CO}_{2}$, which is a greenhouse gas, emissions also raised important issues on environmental problems [2]. For these reasons, biofuels (liquid and gaseous) have been subject to intensive research work all over the world because they are extraordinarily attractive alternative fuels. Biodiesel (liquid fuel) is nontoxic, renewable, and biodegradable, and is the most promising alternative energy for diesel engines [3]. Biodiesel is produced by a transesterification process with renewable agricultural resources like vegetable oils, animal fats and waste oils. The principal advantages of biodiesel are that it reduces or suppresses the formation of sulfur dioxide $\left(\mathrm{SO}_{2}\right), \mathrm{CO}, \mathrm{HC}$ and $\mathrm{PM}$ emissions during the combustion process due to its low sulfur, low aromatic, and the presence of oxygen-containing compounds [4]. In addition, biodiesel has good ignition ability in engine due to its relatively high cetane number compared to that of conventional diesel fuel [5]. Biogas (gaseous fuel) promisingly, is also to be abundantly available as fuel for $\mathrm{CI}$ engines and is regarded as an alternative clean energy resource in view of its friendly environmental nature because it has lower impact on pollution compared to fossil liquid fuels [6]. In general, it is produced by the anaerobic fermentation of organic waste in landfills and the anaerobic digestion of sludge, crops, and agroindustrial byproducts and animal organic waste [7]. Methane $\left(\mathrm{CH}_{4}\right)$ is the main component (about over $65 \%$ by vol.) of the biogas and exhibits greater resistance to the knock phenomenon due to its higher octane rating and auto-ignition temperature, making it appropriate for engines with high compression ratios. In addition, the carbon content of methane is also relatively low compared to that of conventional diesel fuel, resulting in a significant decrease in pollutant exhaust emissions [8]. Many researchers have studied the combustion and emission characteristics of the dual-fuel engines fueled with gaseous-liquid fuels. Mustafi and Raine [10] experimentally investigated the exhaust 


\section{Available online at $w w w . i j r a t . o r g$}

emission characteristics of a direct injection (DI) diesel engine operated with natural gas or biogasdiesel dual fuels. Their study showed that stable engine operation is possible with natural gas (NG) and biogas fueling without any modifications to either the engine or its operation, and that the PM (about $70 \%$ by mass) and NOx emissions (maximum of $37 \%$ by mass) of duel-fueling are much smaller than those of diesel fueling operating under the same operation. Maji et al [11] investigated the application of compressed natural gas $(\mathrm{CNG})$ in reducing the noise level, specific fuel consumption, and NOx emissions, however, the UHC increased in the dual-fuel mode with a substitution of CNG for $75 \%$ of the diesel fuel. Shen et al [12] investigated the influence of the $\mathrm{CNG}$ ratio, the advance of the pilot injection for diesel fuel and the intake temperature on the combustion process, emissions, and engine performance of a dual-fueled engine. The results showed that the $\mathrm{CNG}$ ratio, pilot injection timing and intake temperature play important roles in the formation of pollutant emissions and the performance of an engine fueled with dual-fuels.

\section{TRANSESTERIFICATION REACTION}

It is most commonly used and important method to reduce the viscosity of vegetable oils. In this process triglyceride reacts with three molecules of alcohol in the presence of a catalyst producing a mixture of fatty acids, alkyl ester and glycerol. The process of removal of all the glycerol and the fatty acids from the vegetable oil in the presence of a catalyst is called esterification. The parameter such as temperature, molar ratio and catalyst concentration that affect the transesterification of Calophyllum Inophyllum oil were optimized initially. The transesterification set up houses $2 \mathrm{~L}$ capacity, round bottom flask provided with three necks that was placed in a water container for heating the oil. A heater with a temperature regulator was placed in the round bottom flask. A high speed motor with a magnetic stirrer was used for vigorous mixing of the oil. In the transesterification process triglycerides of Calophyllum Inophyllum oil reacts with methyl alcohol in the presence of catalyst $(\mathrm{NaOH})$ to produce a fatty acid ester and glycerol. In this process $1000 \mathrm{~g}$ Calophyllum Inophyllum oil, $230 \mathrm{~g}$ methanol and $8 \mathrm{~g}$ sodium hydroxide pellets were placed in the round bottom flask. The contents were heated to $70^{\circ} \mathrm{C}$ and stirred vigorously for one hour to promote ester formation. The mixture was next transferred to a separating funnel and allowed to settle under gravity overnight. The upper layer in the separating funnel consists of ester whist the lower layer is glycerol which was removed. The separated ester with $250 \mathrm{~g}$ hot water and allowed to settle under gravity for 24 hours. Water washing separates residual fatty acids and catalyst and these were removed using a separating funnel. Finally we get Calophyllum Inophyllum Methyl Ester.

\subsection{Properties Of Fuels}

Table 1 Properties of fuels

\begin{tabular}{|c|c|c|c|}
\hline Properties & Diesel & CIME & CBG \\
\hline $\begin{array}{c}\text { Viscosity } \\
\text { @ } 40^{\circ} \mathrm{C} \\
(\mathrm{CSt})\end{array}$ & 3.59 & 5.14 & --- \\
\hline $\begin{array}{c}\text { Flash point } \\
\left({ }^{\circ} \mathrm{C}\right)\end{array}$ & 56 & 179 & --- \\
\hline $\begin{array}{c}\text { Calorific } \\
\text { value } \\
(\mathrm{MJ} / \mathrm{kg})\end{array}$ & 42.12 & 39.22 & 36.54 \\
\hline $\begin{array}{c}\text { Density } \\
\left(\mathrm{kg} / \mathrm{m}^{3}\right)\end{array}$ & 827 & 858 & 0.68 \\
\hline
\end{tabular}

\subsection{Composition of $C B G$}

Table 2 Composition of CBG

\begin{tabular}{|c|c|}
\hline Composition & $\begin{array}{c}\% \\
\text { Volume }\end{array}$ \\
\hline $\mathrm{CH}_{4}$ & 89 \\
\hline $\mathrm{H}_{2} \mathrm{~S}$ & 1.5 \\
\hline $\mathrm{CO}_{2}$ & 8 \\
\hline $\mathrm{N}_{2}$ & 1.5 \\
\hline
\end{tabular}




\section{EXPERIMENTAL SETUP}

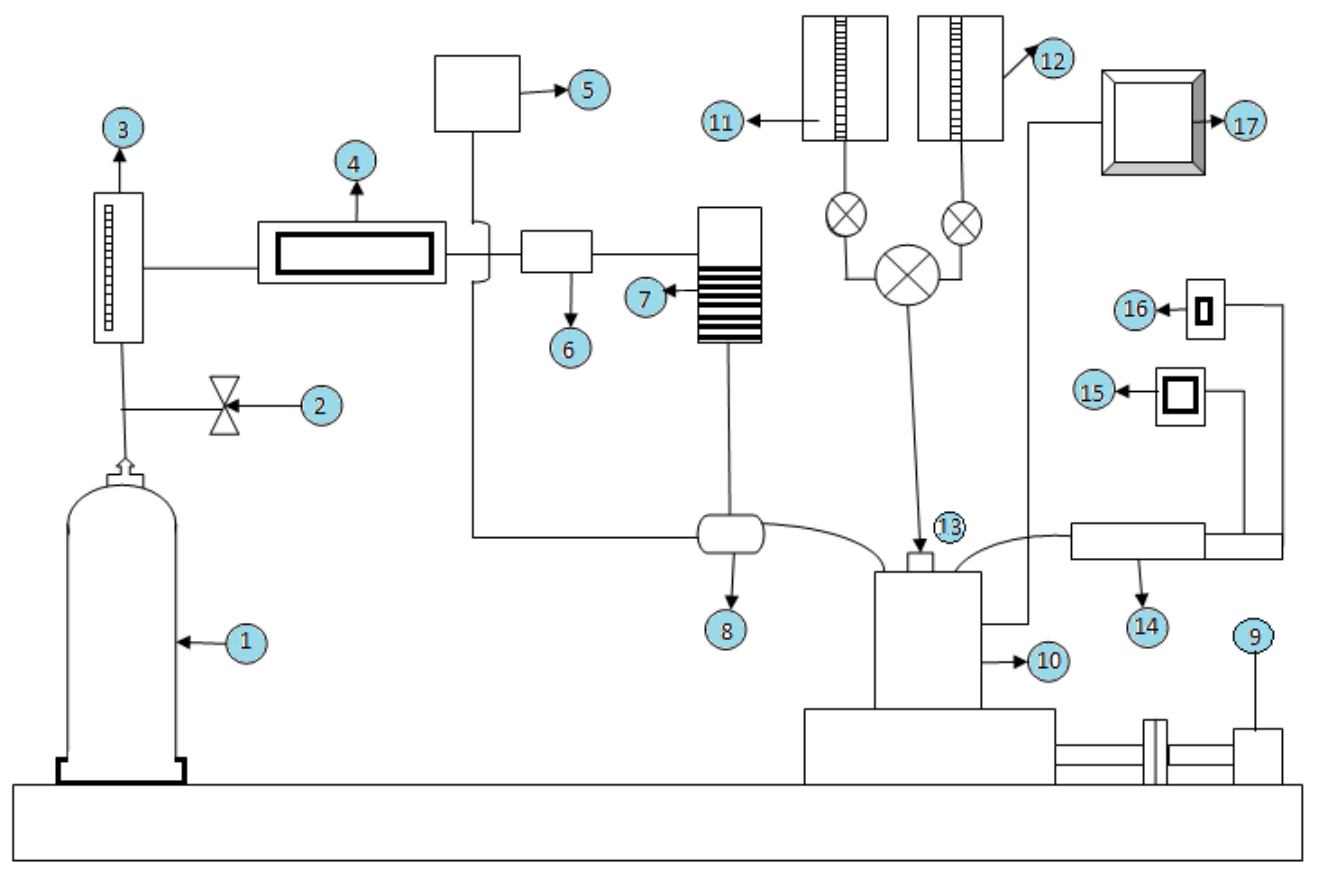

Fig 1 Schematic view of experimental setup for dual fuel engine

1-CBG cylinder, 2-Pressure regulator, 3-CBG rotameter, 4-Gas flow meter, 5-Air box, 6-Dry flame arrester, 7-Wet flame trap, 8-Mixing chamber, 9-Eddy current dynamometer, 10-Diesel engine, 11-Diesel tank, 12-Biodiesel tank, 13-Fuel injector, 14-Exhaust gas line, 15-Exhaust gas analyzer, 16-Smoke meter, 17-Computer connected to engine

\subsection{Engine Specifications}

Table 3 Engine specifications

\begin{tabular}{|c|c|}
\hline Engine parameter & Specifications \\
\hline Type & $\begin{array}{c}\text { TV1 (Kirloskar } \\
\text { make) }\end{array}$ \\
\hline No. of cylinders & 1 \\
\hline No. of strokes & 4 \\
\hline Rated power & $5.2 \mathrm{~kW}$ \\
\hline Bore $\times$ Stroke & $87.5 \mathrm{~mm} \times 100$ \\
& $17.5: 1$ \\
\hline Compression ratio & Eddy current \\
\hline Dynamometer & 230 bar \\
\hline Injection pressure &
\end{tabular}

The experiment was carried out to investigate the performance and emission characteristics of $\mathrm{CI}$ engine fuelled with Diesel-CBG and CIME-CBG in a stationary single cylinder diesel engine for different injection timing. Technical specifications of an engine were given above. The engine was coupled with eddy current dynamometer. The performance and emission parameters were analyzed from the graphs regarding brake thermal efficiency, brake specific fuel consumption, hydrocarbon, carbon monoxide, nitric oxide and smoke opacity.

\section{RESULTS AND DISCUSSION \\ 4.1. Brake Thermal Efficiency}

As the injection timing is advanced from $19^{\circ}$ BTDC to $27^{\circ} \mathrm{BTDC}$, the thermal efficiency increased for $80 \%$ and $100 \%$ loads. The reason for this increased thermal efficiency is that, more time would be available for CBG fuel burning and results in better performance with improved thermal efficiency. 


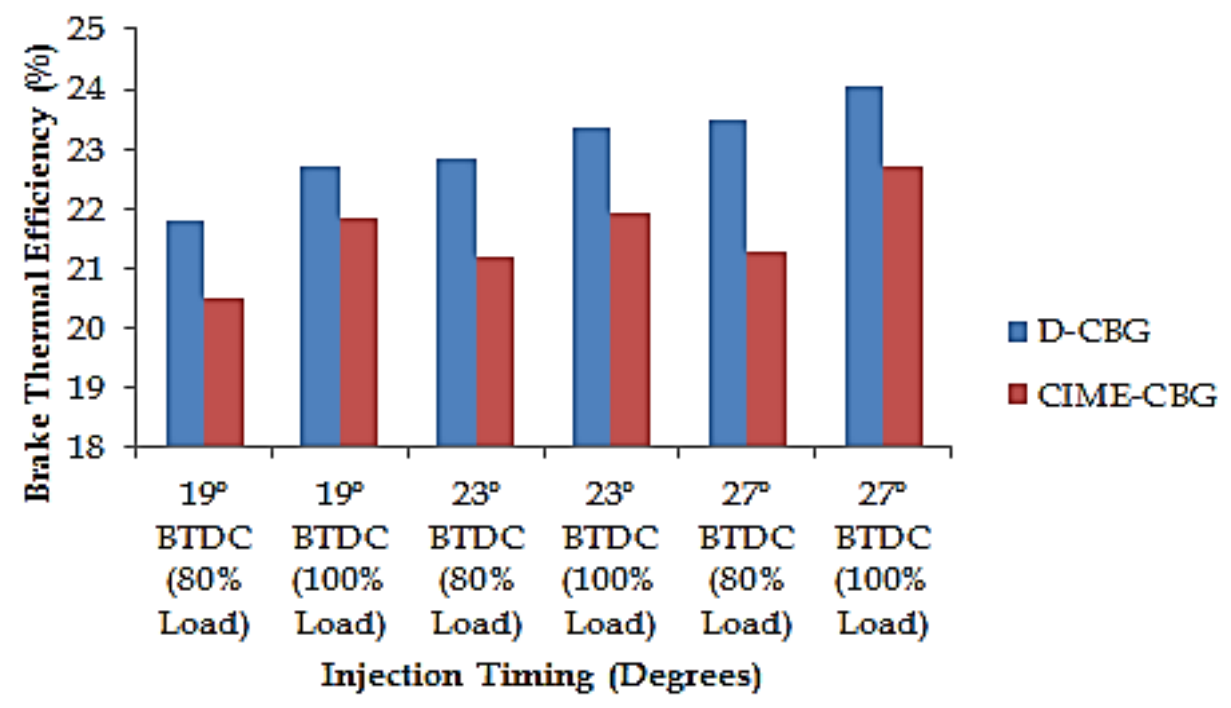

Fig 2 Variation of brake thermal efficiency with injection timing

\subsection{Brake Specific Fuel Consumption}

Increase in injection timing from $19^{\circ} \mathrm{BTDC}$ to $27^{\circ}$ BTDC, it was found decrement in fuel consumption values. The reason for this may be due to sufficient time availability for evaporation and mixing of fuel and air with increased premixed combustion and lower diffusion combustion.

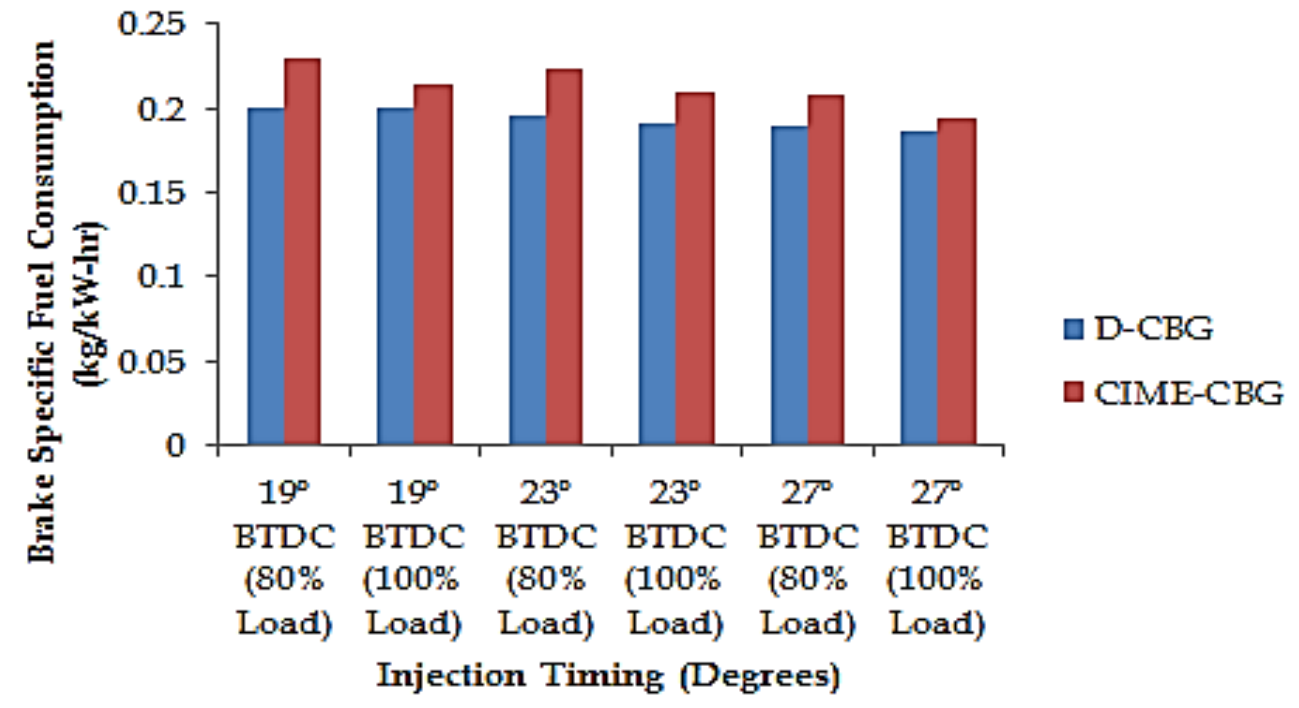

Fig 3 Variation of brake specific fuel consumption with injection timing

\subsection{Hydrocarbon Emissions}

As the injection timing increases the hydrocarbon emissions decreased considerably for both loads. The reason for decreased hydrocarbon emissions with increased injection timing could be due to better combustion with increased thermal efficiency. This is due to a longer ignition delay of the mixture with the increased timing advance. The longer ignition delay allows a fuller spray penetration and development, creating a larger amount of the pilot fuel-air-gaseous fuel mixture (or flame propagation region) prior to ignition. The higher combustion rates of this larger premixed regions yields higher combustion temperatures and thus, lowers the hydrocarbon emissions. Hydrocarbon emission levels for Diesel-CBG and CIME-CBG dual fuel operation at 19, 23 and $27^{\circ}$ BTDC injection timing, at $80 \%$ load are found to be 76, 68 and 63 and 84, 74 and 71 ppm respectively. 


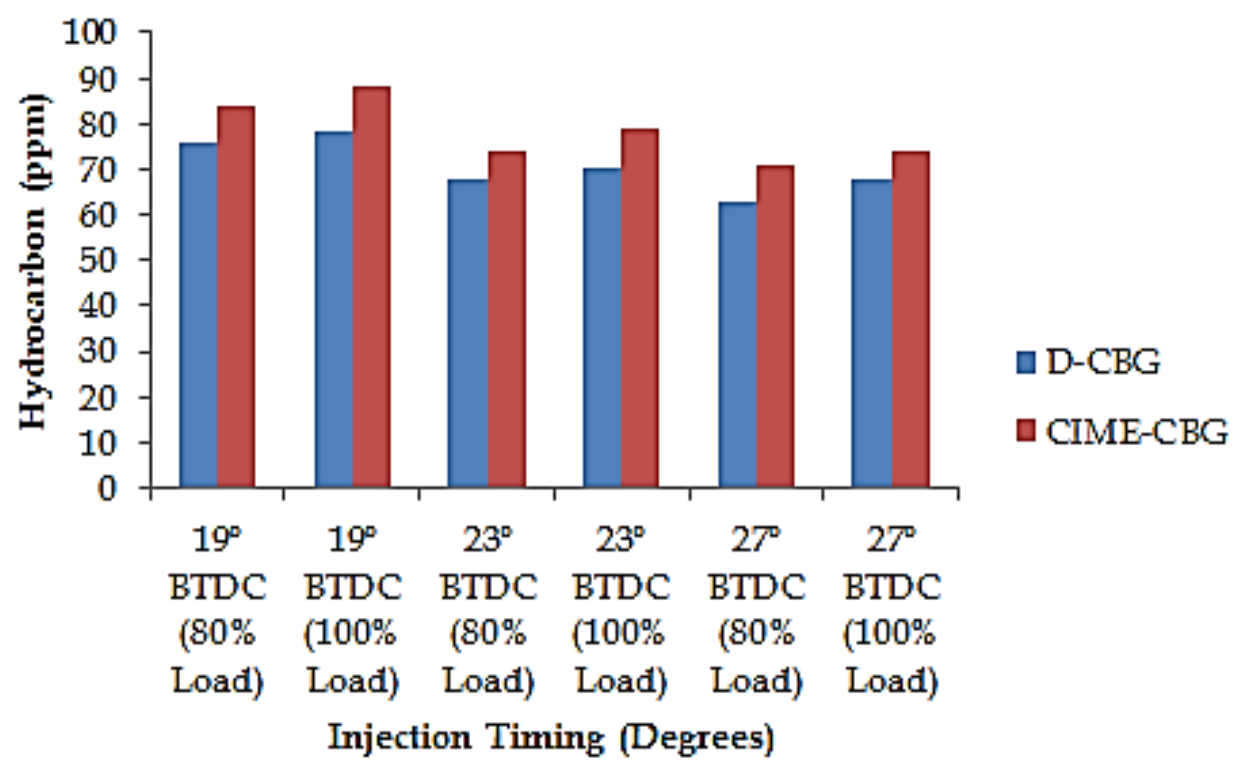

Fig 4 Variation of hydrocarbon emissions with injection timing

\subsection{Carbon Monoxide Emissions}

The emission of carbon monoxide results from incomplete combustion of hydrocarbon fuel. As the injection timing was advanced from $19^{\circ}$ BTDC to $27^{\circ}$ BTDC the carbon monoxide emission decreased considerably. With larger injection advance, overall better combustion and the activity of the partial oxidation reactions reduced the carbon monoxide emissions. Carbon monoxide emission levels for Diesel-CBG and CIME-CBG dual fuel operation at 19,23 and $27^{\circ}$ BTDC injection timing, at $80 \%$ load is found to be $0.21,0.14$ and $0.12 \%$ and $0.24,0.21$ and $0.18 \%$ respectively. At $80 \%$ load and $27^{\circ}$ BTDC the values of carbon monoxide emissions for Diesel-CBG and CIME-CBG were 0.12 and $0.18 \%$ respectively.

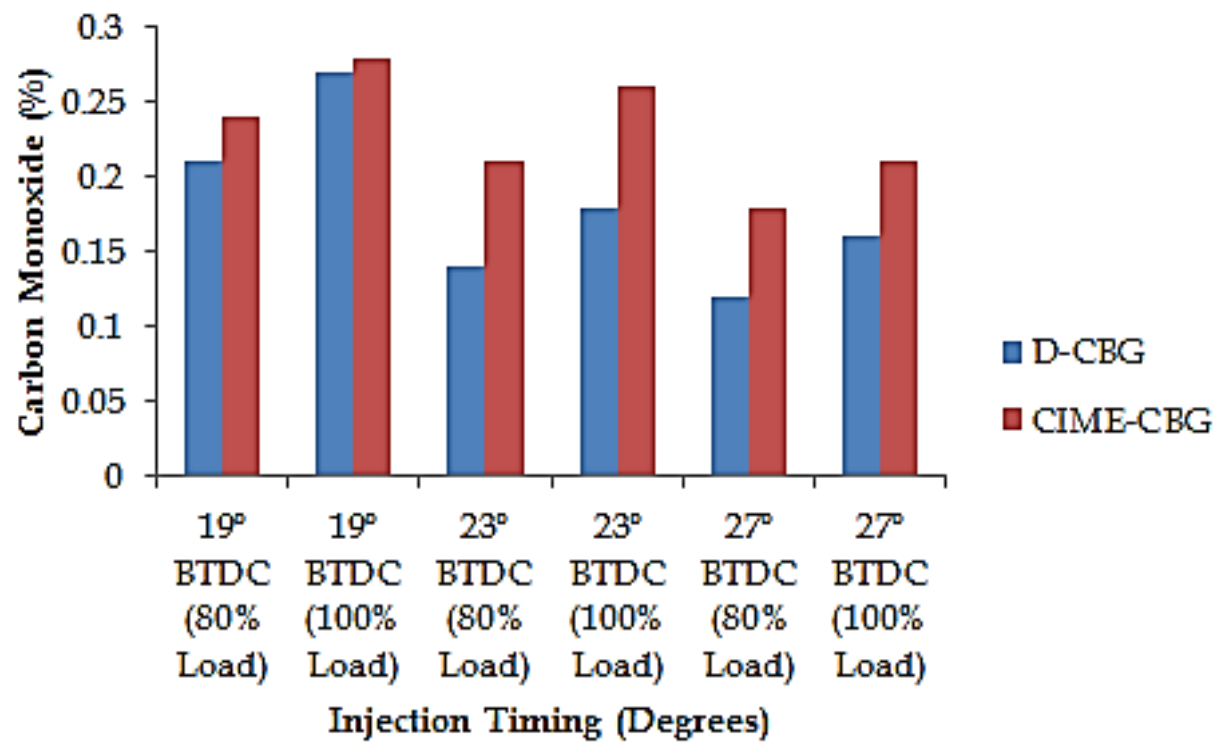

Fig 5 Variation of carbon monoxide emissions with injection timing

\subsection{Nitric Oxide Emissions}

As the injection timing increases the emission of nitric oxide increases considerably. The reason for increased nitric oxide emissions with increased injection timing could be due to better combustion prevailing inside the engine cylinder and more heat released during combustion. nitric oxide emission levels for Diesel-CBG and CIME-CBG dual fuel operation at 19,23 and $27^{\circ} \mathrm{BTDC}$ injection timing 
are found to be 680,890 and 910 and 660,730 and

784 ppm respectively.

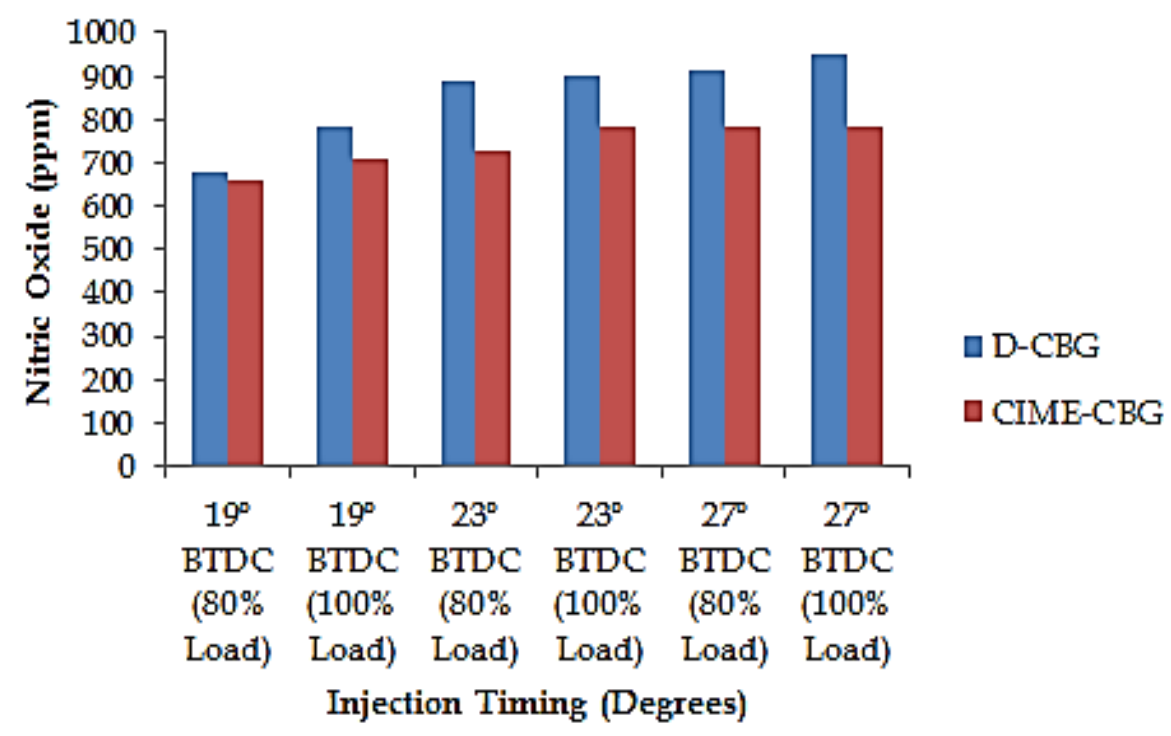

Fig 6 Variation of nitric oxide emissions with injection timing

\subsection{Smoke Emissions}

The smoke opacity decreases with increase in injection timing. This is because of better combustion prevailing inside the engine cylinder. It is also evident that as engine load increases, the smoke emissions increase slightly due to the decrease of air volumetric efficiency in dual fuel mode. Smoke levels for Diesel-CBG and CIMECBG dual fuel operation at 19, 23 and $27^{\circ}$ BTDC injection timing are found to be 66,61 and 64 and 74,68 and $71 \mathrm{HSU}$ respectively at $80 \%$ load.

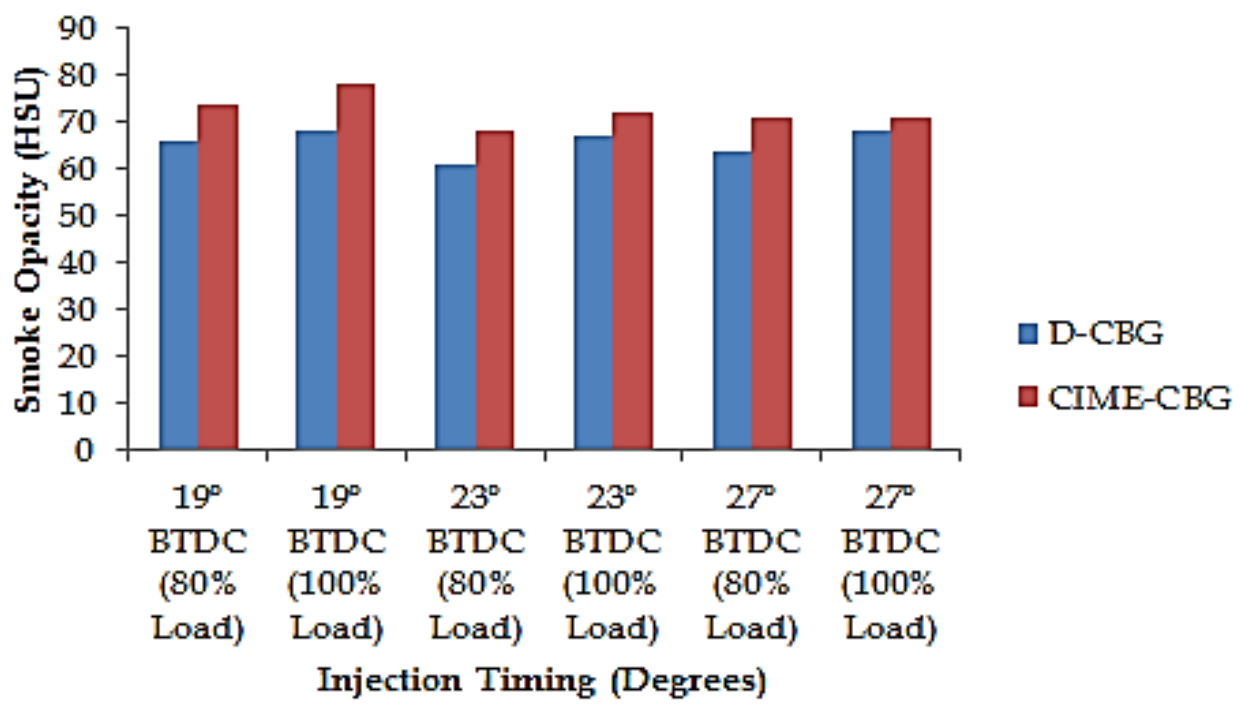

Fig 7 Variation of smoke opacity with injection timing

\section{CONCLUSIONS}

With increase in injection timing from $19^{\circ} \mathrm{BTDC}$ to $27^{\circ}$ BTDC the brake thermal efficiency increases. With increase in injection timing there is increase of NOx values but there is decrease of BSFC, CO,
HC, Smoke emissions. At 100\% load engine gives better performance as compared to $80 \%$ load. Diesel and CBG combination gives better results than CIME and CBG combination in terms of performance and emission characteristics. 
International Journal of Research in Advent Technology, Vol.7, No.4, April 2019

E-ISSN: 2321-9637

Available online at www.ijrat.org

\section{REFERENCES}

[1] R.L.McCormic, C.J.Tennant, R.R.Hayes, S.Black. Regulated Emissions from Biodiesel Tested in Heavy Duty Engines Meeting 2004 Emission Standards. SAE 2005, 2005-01-2200.

[2] S.H.Yoon, S.H.Park, C.S.Lee. Experimental investigation on the fuel properties of biodiesel and its blends at various temperatures. Energy and Fuels, 2008, 22, 652-656.

[3] M.Y.Kim, S.H.Yoon, C.S.Lee. Impact of split injection strategy on the exhaust emissions and soot particulates from a compression ignition engine fueled with neat biodiesel. Energy and Fuels, 2008, 22, 1260-1265.

[4] M.Y.Kim, S.H.Yoon, J.W.Hwang, C.S.Lee. Characteristics of particulate emissions of compression ignition engine fueled with biodiesel derived from soybean. Journal of Engineering for Gas Turbine and Power, 2008, 130(5), 0528051-052805-7.

[5] S.H. Yoon, H.K. Suh, C.S. Lee. Effect of spray and EGR rate on the combustion and emission characteristics of biodiesel fuel in a compression ignition engine. Energy and Fuels, 2009, 23, 1486-1493.

[6] S.H. Park, S.H. Yoon, C.S. Lee. Effect of the temperature variation on properties of biodiesel and biodiesel-ethanol blends fuels. Oil \& Gas Science and Technology, 2008, 63(6), 737-745.

[7] C. Rahmouni, M. Tazerout, O. Le Corre. A method to determine biogas composition for combustion control. SAE 2002, 200201-1708.

[8] C. Tricase, M. Lombardi. State of the art and prospects of Italian biogas production from animal sewage: technical-economic considerations. Renewable Energy, 2009, $34,477-485$.

[9] B.B. Sahoo, N. Sahoo, U.K. Saha. Effect of engine parameters and type of gaseous fuel on the performance of dual-fuel gas diesel engines - A critical review. Renewable and Sustainable Energy Reviews, 2009, 13, 1151-1184.

[10] N.N. Mustafi, R.R. Raine. A study of the emissions of a dual fuel engine operating with alternative gaseous fuels.SAE2008, 2008-01-1394.

[11] S. Maji, Amit Pal, B.B. Arora. Use of $\mathrm{CNG}$ and diesel in CI engines in dual fuel mode.SAE 2008, 2008-28-0072.

[12] S. Jie, Q. Jun, Y. Mingfa. Turbocharged diesel/CNG dual-fuel engines with intercooler: combustion, emissions and performance. SAE 2003, 2003-01-3082.
[13] M.D. Phan, W. Kanit. Study on biogas premixed charge diesel dual fuelled engine. Energy Conversion and Management, 2007, 48, 2286-2308.

[14] N. Bahman, P. Vahab, N. Gholamhassan, Y. Talal, G. Barat. Experimental investigation of performance and emission parameters of a small diesel engine using CNG and biodiesel.SAE 2007, 2007-320075.

[15] James P. Szybist, Stephen R. Kirby, Andre L. Boehman. NOx emissions of alternative diesel fuels: a comparative analysis of biodiesel and FT diesel. Energy and Fuels, 2005, 19, 1484-1492.

[16] G.A. Karim. The dual fuel engine of the compression ignition type-prospects, problems and solutions-a review. SAE 1983, 831073.

[17] G. Prakash, A. Ramesh, A.B. Shaik. An approach for estimation of ignition delay in a dual fuel engine.SAE 1999, 1999-010232.

[18] Y. Zhang, A.L. Boehman. Impact of biodiesel on NOx emissions in s common rail direct injection diesel engine. Energy and Fuels, 2007, 21, 2003-2012.

[19]I. Saanum, M. Bysveen, J.E. Hustad. Study of particulate matter, NOx and hydrocarbon emissions from a diesel engine fueled with diesel oil and biodiesel with fumigation of hydrogen, methane and propane. SAE 2008, 2008-01-1809.

[20]A. Upatnieks, C.J. Muller. Clean, controlled DI diesel combustion using dilute, cool charge gas and a shortignition-delay, oxyenated fuel, SAE 2005, 2005-01-0363.

[21]G.A. Karim, A review of combustion processes in the dual fuel engine-the gas diesel engine. Progress in Energy and Combustion Science, 1980, 6, 277-285.

[22] C.S. Weaver, S.H. Turner. Dual fuel natural gas/diesel engines: technology, performance, and emissions. SAE 1994, 940548.

[23]P. Verma, V.M. Singh. Assessment of diesel engine performance using cotton seed biodiesel. Integrated Research Advances, 2014, 1(1), 1-4.

[24] P.A. Harari. Experimental Investigation on the Performance and emission characteristics of compression ignition engine fuelled with various blends of water melon biodiesel. Integrated Research Advances, 2017, 4(1), 18-23.

[25]D.N. Basavarajappa, N. R. Banapurmath, S.V. Khandal, G. Manavendra. Performance Evaluation of Common Rail Direct Injection (CRDI) Engine Fuelled 


\section{Available online at $w w w . i j r a t . o r g$}

with Uppage Oil Methyl Ester (UOME). Int. J. Renewable Energy Development, 2015, 4(1), 1-10.

[26] N.R. Banapurmath, P.G. Tewari, RS. Hosmath. Performance and emission characteristics of a DI compression ignition engine operated on Honge, Jatropha and sesame oil methyl esters. Renewable Energy, 2008, 33, 1982-1988.

[27] V.S. Yaliwal, N.R. Banapurmath, N.M. Gireesh, R.S. Hosmath, Teresa Donateo, P.G. Tewari. Effect of nozzle and combustion chamber geometry on the performance of a diesel engine operated on dual fuel mode using renewable fuels. Renewable Energy, 2016, 93, 483-501.

[28] Ranganatha Swamy L., T.K. Chandrashekar, N.R. Banapurmath, P. Nashipudi. Effect of Injection Timing,
Combustion Chamber Shapes and Nozzle Geometry on the Diesel Engine Performance. Universal Journal of Petroleum Sciences, 2014, 2, 74-95.

[29] D.N. Basavarajappa, N. R. Banapurmath, S.V. Khandal, G. Manavendra. Effect of Combustion Chamber Shapes \& Injection Strategies on the Performance of Uppage Biodiesel Operated Diesel Engines. Universal J. Renewable Energy, 2014, 2, 67-98.

[30] N.R. Banapurmath, P.G. Tewari, V.S. Yaliwal, Satish Kambalimath, Y.H Basavarajappa. Combustion characteristics of a 4-stroke CI engine operated on Honge oil, Neem and Rice Bran oils when directly injected and dual fuelled with producer gas induction. Renewable Energy, 2009, 34, 1877-1884. 